\title{
UNIVERSITY OF TEXAS AT AUSTIN RADIOCARBON DATES IX
}

\author{
S. VALASTRO, JR., E. MOTT DAVIS, \\ and ALEJANDRA G. VARELA
}

Radiocarbon Laboratory, Balcones Research Center,

The University of Texas at Austin

This laboratory is now a branch of the Texas Memorial Museum of the University of Texas at Austin. This list reports $\mathrm{C}^{14}$ measurements made in projects completed between October 1969 and August 1971. A number of major projects are still in progress and are to be reported later. Age calculations are based on $\mathrm{C}^{14}$ half-life of $5568 \mathrm{yr}$ and modern standard of $95 \%$ of NBS oxalic acid. Deviations reported are based on counting statistics of sample, background, and modern, and are $\pm l_{\sigma}$ except that when sample count approaches either modern or background, $2 \sigma$ limits are reported. Except where noted, $\mathrm{C}^{12} / \mathrm{C}^{13}$ measurements have not been made, and results are not corrected for $\mathrm{C}^{13}$ fractionation. The laboratory uses liquid scintillation counting of benzene, with $\mathrm{Li}_{2} \mathrm{C}_{2}$ and vanadium-activated catalyst in preparation; chemical yields average $88 \%$. The counter is a Packard TriCarb Model 3002.

We acknowledge with gratitude the technical and secretarial assistance of Teresia Lopez-Cepero of our staff, and the administrative support and assistance of W. W. Newcomb and M. Louise Glass of the Texas Memorial Museum.

\section{CHECK SAMPLES}

Ground water samples subm. by M. A. Tamers, IVIC lab., for crossdating. Samples received as $\mathrm{SrCO}_{2}$ powder; although dry when shipped, they arrived damp and matted. Each sample was split in our lab. and the 2 parts prepared and counted separately; individual results are given in parentheses.

\begin{tabular}{|c|c|c|c|c|c|}
\hline Tx no. & Age & $\%$ Modern & IVIC no. & $\%$ Modern & Ref. \\
\hline Tx-852 & $\begin{array}{l}11,920 \pm 120 \\
(11,940 \pm 160 \\
11,900 \pm 170)\end{array}$ & $22.61 \pm 0.36$ & IVIC-216 & $18.9 \pm 0.35$ & $\begin{array}{l}\text { R., } 1966, \\
\text { v. } 8, \text { p. } 205\end{array}$ \\
\hline Tx-853 & $\begin{array}{l}4170 \pm 50 \\
(4250 \pm 70 \\
4090 \pm 70)\end{array}$ & $58.93 \pm 0.41$ & IVIC-222 & $57.3 \pm 0.5$ & $\begin{array}{l}\text { R., } 1966, \\
\text { v. } 8, \text { p. } 206\end{array}$ \\
\hline Tx-854 & $\begin{array}{l}10,130 \pm 90 \\
(10,140 \pm 100 \\
10,110 \pm 160)\end{array}$ & $28.30 \pm 0.36$ & IVIC-271 & $26.2 \pm 0.4$ & $\begin{array}{l}\text { R., } 1967, \\
\text { v. } 9, \text { p. } 238\end{array}$ \\
\hline
\end{tabular}

General Comment (M.A.T.): Tx-852 and IVIC-216 show significant difference, but other 2 measurements are statistically indistinguishable. 
II. GEOLOGIC AND OCEANOGRAPHIC SAMPLES

A. Laguna Madre Flats, $S$ Texas coast

Samples from wind-tidal flats in Laguna Madre at land bridge, Kenedy Co., $72 \mathrm{~km} \mathrm{~S}$ of Corpus Christi, Texas (except Tx-1118, q.v.), coll. in study of sedimentation rates and formation of authigenic minerals. Coll. 1969, 1970 and subm. by J. A. Miller, Dept. Geol. Sci., Univ. Texas, Austin. In titles of samples from trenches and cores, 2nd figure is depth below surface in inches. Alts. are above mean sea level. $\delta \mathbf{C}^{14}$ values in parts per mil.

\section{Tx-1083. BR5-SNL}

$$
\begin{aligned}
& 5190 \pm 210 \\
& 3240 \text { B.C. } \\
\delta C^{14}= & -475 \pm 6.0
\end{aligned}
$$

Snail shells, indicating a grass-flat environment, from channel-dredge spoil from depth $3 \mathrm{~m}$. (alt. $<+.30 \mathrm{~m})$ at site BR5 $\left(26^{\circ} 49^{\prime} \mathrm{N}\right.$ Lat, $97^{\circ}$ $27^{\prime} 30^{\prime \prime}$ W Long).

\section{Tx-1084. 1 TRES-SNL}

$$
\begin{array}{r}
890 \pm 90 \\
\text { A.D. } 1060 \\
\delta C^{14}=-105 \pm 6.7
\end{array}
$$

Snail shells from clay dune on Tres Marias I. $\left(26^{\circ} 56^{\prime} \mathrm{N}\right.$ Lat, $97^{\circ} 31^{\prime}$ W Long), alt. ca. $1 \mathrm{~m}$.

\section{Tx-1085. Core 104-30}

$460 \pm 450$

$\mathrm{CaCO}_{3}$ layer from lagoon sediment, in Core $104\left(26^{\circ} 56^{\prime} \mathrm{N}\right.$ Lat, $97^{\circ}$ $29^{\prime}$ W Long). Alt. ca. $0.6 \mathrm{~m}$.

\section{Tx-1086. Core 105-37}

$$
\begin{aligned}
& 2510 \pm 130 \\
& 560 \text { B.C. }
\end{aligned}
$$

$\mathrm{CaCO}_{3}$ layer from lagoon sediment, in Core $105\left(26^{\circ} 56^{\prime} \mathrm{N}\right.$ Lat, $97^{\circ}$ $31^{\prime} \mathrm{W}$ Long). Surface alt. ca. $0.6 \mathrm{~m}$.

\section{Tx-1087. Core 106-35}

$$
\begin{aligned}
2630 & \pm 385 \\
680 & \text { B.C. } \\
\delta C^{14}=-278 & \pm 19.0
\end{aligned}
$$

$\mathrm{CaCO}_{3}$ layer from lagoon sediment, in Core $106\left(26^{\circ} 57^{\prime} \mathrm{N}\right.$ Lat, $97^{\circ}$ $30^{\prime}$ W Long). Alt. $0.6 \mathrm{~m}$.

\section{Tx-1091. Core 109-5}

$670 \pm 100$

$\mathrm{CaCO}_{3}$ from layer in lagoon sediment, Core $109\left(26^{\circ} 59^{\prime} \mathrm{N}\right.$ Lat, $97^{\circ}$ $31^{\prime}$ W Long). Alt. ca. $0.6 \mathrm{~m}$.

Tx-1100. Core 34-40

$4700 \pm 150$ 2750 B.C.

$$
\delta C^{14}=-\mathbf{4 4 2} \pm \mathbf{5 . 0}
$$

$\mathrm{CaCO}_{3}$ from carbonate zone in lagoon sediments, Core $34\left(26^{\circ} 54^{\prime}\right.$ $00^{\prime \prime} \mathrm{N} \mathrm{Lat,} 97^{\circ} 31^{\prime} 15^{\prime \prime} \mathrm{W}$ Long), alt. ca. $1 \mathrm{~m}$. 
Tx-1103. Core 32-23

$2020 \pm 170$

70 B.C.

$\delta C^{14}=-222 \pm 9.8$

Algal mats from lagoon sediments, depth 6.9 to $7.5 \mathrm{~m}$. in Core 32

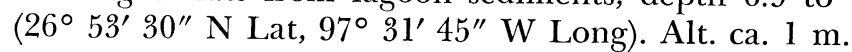

Tx-1111. Core 28-20

$$
\begin{array}{r}
810 \pm 170 \\
\text { A.D. } 1140 \\
\delta C^{14}=-95.7 \pm 12.8
\end{array}
$$

Plant fragments from channel fill (sand) in Core 28 (26 $53^{\circ} \mathrm{N}$ Lat, $97^{\circ} 31^{\prime} 50^{\prime \prime} \mathrm{W}$ Long), adjacent to recent lagoon sediments; alt. ca. $1 \mathrm{~m}$.

Tx-1112. Core 55-33

$$
\begin{array}{r}
1830 \pm 180 \\
\text { A.D. } 120 \\
\delta C^{14}=-203.9 \pm 10.7
\end{array}
$$

Algal mat from shoal in filled lagoon, Core $55\left(26^{\circ} 56^{\prime} 40^{\prime \prime} \mathrm{N}\right.$ Lat, $97^{\circ} 29^{\prime} 40^{\prime \prime}$ W Long). Alt. ca. $0.3 \mathrm{~m}$.

\section{Tx-1118. Core 100-3}

$$
\begin{array}{r}
1700 \pm 60 \\
\text { A.D. } 250 \\
\delta C^{14}=-190 \pm 4.4
\end{array}
$$

Shell material from Core 100 in recent lagoon sediments, ca. $50 \mathrm{~km}$ $\mathrm{S}$ of Corpus Christi on Laguna Madre Middle Ground $\left(27^{\circ} 09^{\prime} \mathrm{N}\right.$ Lat, $97^{\circ} 25^{\prime} \mathrm{W}$ Long). Depth $1 \mathrm{~m}$, alt. ca. . $.30 \mathrm{~m}$.

\section{TORO series}

Dolomite, $\mathrm{MaCa}\left(\mathrm{CO}_{3}\right)_{2}$, from lagoon sediment at TORO-1 and TORO-2 sites ( $26^{\circ} 56^{\prime} \mathrm{N}$ Lat, $97^{\circ} 29^{\prime} \mathrm{W}$ Long). From spoil bank adjacent to dredged channel. From ca. $3.75 \mathrm{~m}$ depth; alt. $1 \mathrm{~m}$.

Tx-1078. TORO-1

\section{Tx-1079. TORO-2}

$$
\begin{array}{r}
2150 \pm 80 \\
200 \text { в.C. } \\
\delta C^{14}=-234 \pm 4.7 \\
2400 \pm 1300 \\
\text { Modern } \\
\delta C^{14}=-258 \pm 66.3
\end{array}
$$

\section{Trench 102 series}

Algal material from completely filled portion of lagoon, Trench 102 (26 $56^{\circ} 9^{\prime} \mathrm{N}$ Lat, $97^{\circ} 29^{\prime} \mathrm{W}$ Long). Alt. ca. $1.07 \mathrm{~m}$.

Tx-1080. Trench 102, surface

\section{Tx-1081. Trench 102, $7.6 \mathrm{~cm}$}

$$
\begin{array}{r}
\text { Modern } \\
\delta \boldsymbol{C}^{14}=+\mathbf{1 9 . 6 8} \pm \mathbf{8 . 7} \\
\mathbf{3 4 0} \pm \mathbf{5 0} \\
\text { A.D. } 1610 \\
\delta \boldsymbol{C}^{14}=-\mathbf{4 5} \pm \mathbf{6 . 3} \\
\mathbf{- 3 8} \pm \mathbf{6 . 4}
\end{array}
$$

Sample was split and the 2 parts prepared and counted separately: $370 \pm 70$ and $310 \pm 70$. 
Tx-1082. Trench 102, $30.5 \mathrm{~cm}$

$$
\mathbf{7 0 0} \pm \mathbf{7 0}
$$

A.D. 1250

$\delta C^{14}=-83 \pm 5.5$

\section{Core 108 series}

$\mathrm{CaCO}_{3}$ samples from layer in lagoon sediment, Core $108\left(26^{\circ} 58^{\prime} \mathrm{N}\right.$ Lat, $97^{\circ} 30^{\prime} \mathrm{W}$ Long). Depth in Core $79 \mathrm{~cm}$. Alt. .30 m.

Tx-1089. Core 108-31

$$
\begin{array}{r}
1750 \pm 170 \\
\text { A.D. } 200 \\
\delta C^{14}=-195 \pm 10.8 \\
\mathbf{3 9 3 0} \pm \mathbf{7 0 0} \\
\text { A.D. } 1980 \\
\delta C^{14}=-\mathbf{3 8 6} \pm \mathbf{2 5 . 2}
\end{array}
$$

Tx-1090. Core 108-37

\section{Core 70 series}

Algal mat and marl $\left(\mathrm{CaMgCO}_{3}\right)$ from lagoon sediments in Core 70 (26 $56^{\circ} 30^{\prime \prime} \mathrm{N}$ Lat, $97^{\circ} 29^{\prime} 30^{\prime \prime} \mathrm{W}$ Long); S portion of Land Bridge. Alt. ca. $0.6 \mathrm{~m}$.

Tx-1092. Core 70-10, algal mat

Tx-1093. Core 70-32, algal mat

Tx-1094. Core 70-63, marl

$$
\begin{array}{r}
\mathbf{5 7 0} \pm \mathbf{1 1 0} \\
\text { A.D. } 1380 \\
\delta \boldsymbol{C}^{14}=-\mathbf{6 8} \pm \mathbf{9 . 3} \\
\mathbf{1 6 8 0} \pm \mathbf{1 4 0} \\
\text { A.D. } 270 \\
\delta \boldsymbol{C}^{14}=-\mathbf{1 8 9} \pm \mathbf{8 . 8} \\
\mathbf{3 4 7 0} \pm \mathbf{1 0 0} \\
\mathbf{1 5 2 0} \mathbf{B . C .} \\
\delta \boldsymbol{C}^{14}=-\mathbf{3 5 0} \pm \mathbf{4 . 7}
\end{array}
$$

\section{Core 67 series}

Samples from carbonate band $\left(\mathrm{MgCaCO}_{3}\right)$ in lagoon sediment indicating highly evaporative environment, in Core $67\left(26^{\circ} 55^{\prime} \mathrm{N}\right.$ Lat, $97^{\circ}$ $27^{\prime} 30^{\prime \prime}$ W Long). Alt. . $30 \mathrm{~m}$.

\section{Tx-1095. Core 67-35}

$$
\begin{aligned}
& 3650 \pm 120 \\
& 1700 \text { B.C. } \\
& \delta C^{14}=-364 \pm 5.1 \\
& 4200 \pm 310 \\
& \delta \mathrm{C}^{14}=-407 \pm 10.5
\end{aligned}
$$

Tx-1096. Core 67-43

\section{Core 43 series}

Algal mat and marl $\left(\mathrm{CaMgCO}_{3}\right)$ from lagoon sediments, Core 43, $\mathrm{NW}$ portion of Land Bridge (26 $58^{\prime} \mathrm{N}$ Lat, $97^{\circ} 31^{\prime} 20^{\prime \prime} \mathrm{W}$ Long). Alt. ca. $1 \mathrm{~m}$.

Tx-1097. Core 43-8, algal mat

$$
\begin{array}{r}
260 \pm 60 \\
\text { A.D. } 1690 \\
\delta C^{14}=-32 \pm 5.7
\end{array}
$$


Tx-1098. Core 43-60, algal mat

$2480 \pm 70$

530 B.C.

$\delta \boldsymbol{C}^{14}=-265.8 \pm 4.1$

Tx-1099. Core 43-60, marl

$3120 \pm 70$

1170 B.c.

$\delta C^{14}=-322 \pm 3.9$

\section{Core 45 series}

$\mathrm{CaCO}_{3}$ (lime cement and shells) and algal mat from lagoon sediments, Core 45 ( $26^{\circ} 57^{\prime} 30^{\prime \prime} \mathrm{N}$ Lat, $97^{\circ} 31^{\prime} 30^{\prime \prime} \mathrm{W}$ Long). Alt. ca. $1 \mathrm{~m}$.

Tx-1101. Core 45-32, $\mathrm{CaCO}_{3}$

$$
\begin{array}{r}
\mathbf{3 0 7 0} \pm \mathbf{7 0} \\
\mathbf{1 1 2 0} \text { B.C. } \\
\delta \boldsymbol{C}^{14}=-\mathbf{3 1 7} \pm \mathbf{3 . 9} \\
\mathbf{1 2 2 0} \pm \mathbf{1 0 0} \\
\text { A.D. } 730 \\
\delta \boldsymbol{C}^{14}=-\mathbf{1 4 0} \pm \mathbf{7 . 1}
\end{array}
$$

Tx-1102. Core 45-17, algal mat

\section{Core 74 series}

Algal mat from lagoon sediments, Core $74\left(26^{\circ} 49^{\prime} \mathrm{N}\right.$ Lat, $97^{\circ} 29^{\prime}$ $30^{\prime \prime}$ W Long). Alt. ca. $0.3 \mathrm{~m}$.

\section{Tx-1104. Core 74-4}

Tx-1105. Core 74-18

Tx-1106. Core 74-36

$$
\begin{array}{r}
500 \pm 70 \\
\text { A.D. } 1450 \\
\delta C^{14}=-59 \pm 6.2 \\
780 \pm 110 \\
\text { A.D. } 1170 \\
\delta C^{14}=-92 \pm 9.1 \\
1860 \pm \mathbf{2 3 0} \\
\text { A.D. } 90 \\
\delta C^{14}=-\mathbf{2 0 6} \pm \mathbf{1 4 . 0}
\end{array}
$$

\section{Core 10 series}

Algal mats from lagoon sediments in Core $10\left(26^{\circ} 51^{\prime} 10^{\prime \prime} \mathrm{N}\right.$ Lat, $97^{\circ} 30^{\prime} 15^{\prime \prime} \mathrm{W}$ Long). Alt. ca. $0.6 \mathrm{~m}$.

\section{Tx-1107. Core 10-24}

Tx-1108. Core 10-35

$$
\begin{aligned}
\mathbf{1 6 1 0} \pm 130 \\
\text { A.v. 340 } \\
\delta \boldsymbol{C}^{14}=-\mathbf{1 8 2} \pm \mathbf{8 . 2} \\
\mathbf{2 4 9 0} \pm \mathbf{1 3 0} \\
\mathbf{5 4 0 \text { B.C. }} \\
\delta \boldsymbol{C}^{14}=-\mathbf{2 6 6} \pm \mathbf{6 . 9}
\end{aligned}
$$

\section{Core 20 series}

Algal mats from lagoon sediments in Core $20\left(26^{\circ} 51^{\prime} 30^{\prime \prime} \mathrm{N}\right.$ Lat, $97^{\circ} 31^{\prime} 30^{\prime \prime} \mathrm{W}$ Long). Alt. ca. $0.6 \mathrm{~m}$.

Tx-1109. Core 20-23 to 24-1/2

$$
1410 \pm 170
$$

$$
\text { A.D. } 540
$$$$
\delta C^{14}=-161.1 \pm 11.2
$$ 
Tx-1110. Core 20-33

General Comment on Laguna Madre Flats dates (J.A.M.): algal mat dates indicate rate of sedimentation on land bridge has been gradually decreasing during past $2500 \mathrm{yr}$ from ca. $6.5 \mathrm{~cm}$ per $100 \mathrm{yr}$ to $2.5 \mathrm{~cm}$ per $100 \mathrm{yr}$. This is supported by carbonate dates from within sediments. Algal mat dates also help show that sedimentation rate was not uniform throughout land bridge area. Rather, there were several small basins dominated by different types of sediment with slightly different rates of sedimentation (e.g., Tx-1109, $4.1 \mathrm{~cm}$ per $100 \mathrm{yr}$ as contrasted to Tx-1111, $6.5 \mathrm{~cm}$ per $100 \mathrm{yr}$ ).

Samples of aragonite, magnesium calcite, and dolomite, occurring as marls and thin layers in some sediments, were dated to determine if they were primary or diagenetic. Algal-mat and dolomite samples from same location and essentially same stratigraphic position (e.g., Tx-1098, Tx1099) indicate carbonates were probably deposited with other sediments and are not diagenetic.

Although carbonate dates are consistent and seem valid, most are somewhat older than algal-mat dates from similar horizons (e.g., Tx-1098, Tx-1099). Cause of this age discrepancy is not known; possibly it is related to recycling of old carbon or age difference between surface and interstitial waters.

\section{B. Baffin Bay marl and shell samples, Texas}

Marl (finely divided $\mathrm{CaCO}_{3}$ and $\mathrm{Mg}_{2} \mathrm{CO}_{3}$ mixed with clay) and shell from cores in Baffin Bay, $\mathrm{S}$ coast of Texas. Marl beds underlie much of bay; dates help establish time and rate of deposition. Coll. 1968, 1969 and subm. by E. W. Behrens, Univ. Texas Marine Sci. Inst., Port Aransas, Texas.

Tx-957. BB 12-8-68-A, 470, 510

$2770 \pm 50$

820 B.C.

From core in center of Baffin Bay opposite Negrohead Point $\left(27^{\circ}\right.$ $15^{\prime} 45^{\prime \prime} \mathrm{N}$ Lat, $97^{\circ} 30^{\prime} 00^{\prime \prime} \mathrm{W}$ Long), $-745 \mathrm{~cm}$. Average of 2 runs: 2640 $\pm 80,2890 \pm 70$.

Tx-965. BB 21-5-69-C, 455

$3240 \pm 70$

1290 B.C.

From core in central part of Baffin Bay SSE of Negrohead Point (27ำ $16^{\prime} \mathrm{N}$ Lat, $97^{\circ} 30^{\prime} \mathrm{W}$ Long), $-694 \mathrm{~cm}$.

Baffin Bay 21-5-69-D Marl series

From core in central Baffin Bay SSE of Negrohead Point $\left(27^{\circ} 16^{\prime} \mathrm{N}\right.$ Lat, $97^{\circ} 30^{\prime} \mathrm{W}$ Long).

Tx-956. BB 21-5-69-D, 470

$2460 \pm 80$

$-709 \mathrm{~cm}$. 
Tx-966. BB 21-5-69-D, 771-779

$4050 \pm 80$

$-1010 \mathrm{~cm}$.

2100 B.C.

Tx-967. BB 21-5-69-D, 826-830

$4280 \pm 80$

$-1065 \mathrm{~cm}$.

2330 B.C.

Tx-955. BB 21-5-69-D, 920-940

$3660 \pm 80$

$-1160 \mathrm{~cm}$.

1710 B.c.

\section{Baffin Bay 13-1-69-G Marl series}

From core at mouth of Baffin Bay S of Point of Rocks (27 $17^{\prime} 09^{\prime \prime}$ N Lat, $97^{\circ} 25^{\prime} 24^{\prime \prime}$ W Long).

\section{Tx-962. BB 13-1-69-G, 108-111 \\ $-340 \mathrm{~cm}$.}

Tx-963. BB 13-1-69-G, 490

$-720 \mathrm{~cm}$

$1640 \pm 70$ A.D. 310

Tx-964. BB 13-1-69-G, 547

$-775 \mathrm{~cm}$.

General Comment (E.W.B.): other relevant dates are Tx-658, $2310 \pm 60$ (R., 1970, v. 12, p. 620), on marl from another Baffin Bay core that may be correlative, and Tx-754, $4860 \pm 190$ (ibid.), oldest date on Baffin Bay shells showing effects of hypersaline conditions probably necessary for marl formation. Dates as a whole establish that dolomitic marls were deposited in Baffin bay during a period of known hypersalinity, especially ca. 4300 to 2300 B.P. (see also general comment, below).

\section{Baffin Bay 13-1-69-G Shell series}

Small mollusk and serpulid worm tube fragments, dominant species Anomalocardia cuniemeris, from same core as marl samples Tx-962-964 (above).

\section{Tx-960. BB 13-1-69-G, 129-139 $-360 \mathrm{~cm}$.}

$$
\begin{aligned}
1510 & \pm 50 \\
\text { A.D. } 440 & \\
2580 & \pm \mathbf{8 0}
\end{aligned}
$$

Tx-961. BB 13-1-69-G, 194-216

$-430 \mathrm{~cm}$.

General Comment (E.W.B.): compatibility of marl and shell dates demonstrates that there is no significant isotopic-fraction difference between the 2 carbonate-forming processes. Stable carbon-isotope ratios support this conclusion. Marl and shell dates, taken together, establish limits of radiocarbon dating for correlation in these circumstances. 1) Several dates from each core are required to demonstrate reliability of each date. 
For example, Tx-963 and -955 are out of sequence with other samples from their respective cores and thus must be considered wrong. 2) Samples within a few tens of $\mathrm{cm}$ of each other vertically in a core (e.g., Tx$962,-960$ and $-959,-958,-954)$ correlate to within ca. $300 \mathrm{yr}$ of each other but are not necessarily in proper depth sequence. 3) Samples over one $\mathrm{m}$ apart are generally $>500 \mathrm{yr}$ apart and can be used for correlation and rate of sedimentation determination. Sedimentation rates for Baffin Bay muds have been as great as $2 \mathrm{~mm} / \mathrm{yr}$.

\section{Baffin Bay Serpulid Reef series}

Serpulid worm tubes from core in serpulid reef, mouth of Baffin Bay S of Point of Rocks, S coast of Texas (29 $17^{\prime} 20^{\prime \prime} \mathrm{N}$ Lat, $97^{\circ} 25^{\prime} 10^{\prime \prime}$ W Long). Reef is no longer alive; dated in study of age and ecologic conditions at time of formation. Coll. 1969 and subm. by E. W. Behrens.

\section{Tx-959. BB 13-1-69-A, 80-88}

$2760 \pm 120$

-190 to $800 \mathrm{~cm}$. Average of 2 runs: $2810 \pm 80,2720 \pm 150$.

Tx-958. BB 13-1-69-A, 108-128

$3000 \pm 90$

-210 to $220 \mathrm{~cm}$. Average of 2 runs: $2890 \pm 80,3120 \pm 100$.

1050 B.c.

\section{Tx-954. BB 13-1-69-A, 143-153}

$2920 \pm 80$

\section{-250 to $260 \mathrm{~cm}$.}

General Comment (E.W.B.): other dates bearing on problem, Tx-221Tx-225 (R., 1965, v. 7 , p. 299), range from $<180$ to $345 \pm 130$ and suggest that reefs were formed in historic time; however, present dates demonstrate an earlier period of reef formation ca. 3000 B.P. Both times are within period of environmental hypersalinity.

\section{Craters of the Moon lava flows, Idaho}

Samples assoc. with recent volcanic activity along Great Rift, which extends some $65 \mathrm{~km}$ from area of Craters of the Moon Natl. Monument, Idaho, SE to Crystal Ice Cave. Coll. and subm. by F. M. Bullard, Dept. Geol. Sci., Univ. Texas at Austin.

\section{Carbon Site No. 1 series}

Samples from Carbon Site No. 1, outside Natl. Monument boundary on E margin of lava area, $39.5 \mathrm{~km} \mathrm{~S}$ of Arco, $\mathrm{N}$ central part Sec. 3, T2S, R27E, 100 yd $\mathrm{N}$ of end of road $\left(43^{\circ} 19^{\prime} \mathrm{N}\right.$ Lat, $113^{\circ} 21^{\prime} \mathrm{W}$ Long). Carbonized rootlets of shrubs buried by lava flow coming from Great Rift late in its eruptive history. Coll. 1969.

Tx-899. Craters of the Moon 1-1 $2110 \pm 90$

Carbonized rootlets picked from soil. 


\section{Tx-900. Craters of the Moon 1-2}

Dense anthracite-like carbon picked from soil.

100 B.C.

\section{Tx-901. Craters of the Moon 1-3}

Residue of soil and fine rootlets after larger fragments were picked for Tx-899 and Tx-890.

\section{Tx-902. Craters of the Moon 1-4} soill containing rootlets, without sorting. Comment (F.M.B.): date significantly older than others in series, suggests contamination by older material in soil.

\section{Trench Mortar Flat series}

Samples from tree molds assoc. with Great Rift at Trench Mortar Flat, $6.5 \mathrm{~km} \mathrm{SE}$ of Natl. Monument headquarters $\left(43^{\circ} 25^{\prime} \mathrm{N}\right.$ Lat, $113^{\circ}$ $31^{\prime} 30^{\prime \prime}$ W Long); ca. $24 \mathrm{~km}$ from Carbon Site No. 1 (Tx-899-Tx-902, above). Trees adjacent to rift were buried and coated with lava spatter, converting wood to charcoal. Coll. 1970.

\section{Tx-1157. Craters of the Moon 2-1}

$$
\begin{aligned}
& 2210 \pm 80 \\
& 260 \text { B.C. }
\end{aligned}
$$

Tx-1158. Craters of the Moon 2-1a $2240 \pm 80$

Samples from same tree mold, adjacent to rift. Tx-1157 was tree root in situ.

Tx-1159. Craters of the Moon 2-2

From base of trunk of tree mold on rift.

Tx-1160. Craters of the Moon 2-4

$$
\begin{gathered}
2250 \pm 80 \\
300 \text { B.C. }
\end{gathered}
$$

Small charcoal fragments picked from fill.

\section{Tx-1161. Craters of the Moon 2-4a}

$$
2310 \pm 70
$$

Charred wood fragment. Samples believed to represent same tree, adjacent to rift.

\section{Tx-1162. Craters of the Moon 2-5}

$$
2270 \pm 80
$$

From base of tree mold adjacent to 1 ift, $1 \mathrm{~m}$ from Tx-1160 and Tx1161, above.

\section{Tx-1163. Craters of the Moon 2-6}

From tree mold in pahoehoe flow at NW base of "The Watchman Cinder Cone" (43 $23^{\prime}$ N Lat, $113^{\circ} 29^{\prime} 30^{\prime \prime}$ W Long), adjacent to rift and ca. $5 \mathrm{~km} \mathrm{SE}$ of Tx-1157-Tx-1162, above. Mold was filled with ca. $.30 \mathrm{~m}$ 
cinders overlying charcoal horizon; otherwise open to top of lava flow, which may be one of latest flows in area.

\section{Crystal Ice Cave series}

Charred roots projecting from soil beneath lava flow at entrance to Crystal Ice Cave (Kings Bowl on some maps), $29 \mathrm{~km} \mathrm{~W}$ of Aberdeen, Idaho $\left(42^{\circ} 56^{\prime} \mathrm{N}\right.$ Lat, $113^{\circ} 15^{\prime} \mathrm{W}$ Long), ca. $65 \mathrm{~km} \mathrm{SE}$ of Craters of the Moon. From same area is sample dated $2130 \pm 130$ (Prinz, 1970, p. 946, citing Edwin Olson). This is 1st lava flow from Great Rift. Samples were ca. $0.5 \mathrm{~m}$ apart and may be from same plant.

\section{Tx-1164. Crystal Ice Cave, 2-8}

$$
\begin{aligned}
& 2090 \pm 470 \\
& 140 \text { B.C. }
\end{aligned}
$$

Tx-1165. Crystal Ice Cave, $2-9$

$2360 \pm 150$

410 B.C.

General Comment on Craters of the Moon (F.M.B.): close grouping of all dates around $2200 \mathrm{yr}$ B.P. suggests not only that this is valid date but also that final activity from Great Rift took place through much of its extent.

\section{Lava Flow, Utah}

Tx-1166. Cinder Cone, Utah, 2-10

$660 \pm 170$

Root fragments, not charred, in old soil layer beneath lava flow in Cold Tunnel at Cinder Cone, $11.3 \mathrm{~km} \mathrm{~W}$ of Fillmore, Millard Co., Utah $\left(38^{\circ} 59^{\prime} \mathrm{N}\right.$ Lat, $112^{\circ} 28^{\prime} \mathrm{W}$ Long). Roots appear unrelated to present vegetation; thus may date lava flow. Area is ca. $500 \mathrm{~km} \mathrm{~S}$ of Craters of the Moon, above, and is independent center of recent volcanic activity. General appearance suggests same age as Craters of the Moon lava. Coll. 1970 and subm. by F. M. Bullard. Comment (F.M.B.): age much more recent than Craters of the Moon samples; must await further confirmation.

\section{E. Bermuda}

\section{Bermuda stratigraphy series}

Land snail samples ( $P$. bermudensis zonatus) from various locations on Bermuda, dated to assist completion of stratigraphy of Bermuda (Land et al., 1967). Coll. by S. J. Gould, Harvard Univ.; subm. by L. S. Land, Dept. Geol. Sci., Univ. of Texas, Austin. $\delta \mathrm{C}^{13}$ values relative to PDB III, standard notation and corrections applied.

\section{Tx-1071. Whalebone Bay, L-1034G}

$18,250 \pm 450$

$$
\delta C^{14}=-\mathbf{8 9 7} \pm \mathbf{2 . 6} \%
$$

16,300 в.C.

From nonlithified pocket a few $\mathrm{cm}$ above "disappearing" red soil, NE end of r.r. cut just E of Yellow Fever Graveyard, St. George's I. (32 $21^{\prime} 54^{\prime \prime} \mathrm{N}$ Lat, $64^{\circ} 42^{\prime} 42^{\prime \prime} \mathrm{W}$ Long); represents latest eolianite activity (Southampton) on St. George's I. 
Tx-1072. MeGall's Hill, L-1034R

$21,460 \pm 530$

$\delta C^{14}=-931 \pm 2.6 \%$

19,510 B.c.

$\delta C^{13}=-8.0 \%$

From uppermost nonlithified zone, Southampton Fm, type Saucos Hills sec. for Bermudian stratigraphy $\left(32^{\circ} 18^{\prime} 15^{\prime \prime} \mathrm{N}\right.$ Lat, $64^{\circ} 44^{\prime} 15^{\prime \prime} \mathrm{W}$ Long).

\section{Tx-1073. Bermuda L-1034D}

$24,720 \pm 800$

$$
\delta C^{14}=-954 \pm 2.6 \%
$$

22,770 в.c.

From youngest dunes, in commercial sand quarries, SW end of Bermuda ( $32^{\circ} 15^{\prime} \mathrm{N}$ Lat, $64^{\circ} 51^{\prime} \mathrm{W}$ Long).

\section{Tx-1074. Bermuda L-1034E, F,H,K}

$23,900 \pm 1270$

$$
\delta C^{14}=-949 \pm \mathbf{2 . 6} \%
$$

21,950 в.C.

Combined sample from various localities in uppermost dune ridge, N shore St. George's I. (32 $21^{\prime}$ N Lat, $64^{\circ} 44^{\prime}$ W Long); probably Pembroke in age.

\section{Snail study series, Bermuda}

Snail shells coll. to study possible ingestion of dead carbon from limestone environment, affecting age measurement. Coll. 1970 by S. J. Gould and subm. by L. S. Land.

TX-1218. Bermuda S-R1

$$
\delta C^{14}=+92 \pm 11.2 \%
$$

Recent snails living on red soil behind Biological Sta., St. George's

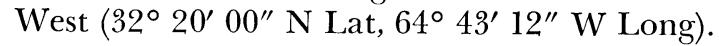

\section{Tx-1219. Bermuda S-R2}

$\delta C^{14}=+347.2 \pm \mathbf{1 6 . 0} \%$

Recent snails living on red soil in field adjacent to Perfume Factory (32 $20^{\prime} 57^{\prime \prime} \mathrm{N}$ Lat, 64 $42^{\prime} 57^{\prime \prime}$ W Long).

\section{Tx-1220. Bermuda S-PI}

$26,440 \pm 970$ $\mathbf{2 4 , 4 5 0}$ B.c.

Snail shells from Shore Hills Soil as exposed in Government Quarry (32 $20^{\prime} 36^{\prime \prime} \mathrm{N}$ Lat, $64^{\circ} 42^{\prime} 27^{\prime \prime} \mathrm{W}$ Long). Soil overlain by rocks dated by $\mathrm{U} / \mathrm{Th}^{230}$ as $120 \times 10^{3} \mathrm{yr}$ (Land et al., 1967).

General Comment (L.S.L.): $\delta \mathrm{C}^{13}$ values of Tx-1071-Tx-1074 are typical for soil atmosphere and for very old Bermuda limestones; snails may obtain $\mathrm{HCO}_{3}$ from underlying limestones, and ages may be too old. Tx-1218 and Tx-1219 negate this premise, as they indicate Recent snail shells have positive $\delta \mathrm{C}^{14}$ values; these ages are minima. Tx-1220, from shells $>120,000 \mathrm{yr}$ old, indicates contamination by Recent carbon, possibly from incipient recrystallization. Thus, dates indicate Southampton Formation is $>20,000$ yr old.

\section{F. Coral Reef Studies, Jamaica}

Samples from coral reefs, just W of ship channel, Discovery Bay, Jamaica (18 $28^{\prime} 06^{\prime \prime} \mathrm{N}$ Lat, $77^{\circ} 24^{\prime} 48^{\prime \prime} \mathrm{W}$ Long). Coll. 1969 and subm. by L. S. Land, Dept. Geol. Sci., Univ. of Texas, Austin. 
Tx-931. JS-Pinnacle, 30"

$$
\begin{aligned}
& 1160 \pm 70 \\
& \text { A.D. } 790 \\
& \delta C^{14}=-134 \pm 5.7 \%
\end{aligned}
$$

Coral (aragonite) from $80 \mathrm{~cm}$ beneath reef front at blast site into deep pinnacle reef at T. F. Goreau Pinnacle I site, $-35 \mathrm{~m}$. Dated to determine rate of framework reef growth of deeper reef with different ecology than Tx-928 and Tx-929, below.

\section{Tx-932. JS-Kaiser Reef Flat, 20"}

$$
650 \pm 60
$$

A.D. 1300

$$
\delta C^{14}=-77 \pm 5.4 \%
$$

Coral encrusted with red algae and Homotrema $\left(\mathrm{CaCO}_{3}\right)$ from Kaiser Reef Flat, just $\mathrm{S}$ of last $A$. palmata, beside R. A. Kinzie III gorgonian transplants, $120 \mathrm{~cm}$ below MSL, $50 \mathrm{~cm}$ beneath back reef flat. Dated to determine rate of accretion of present reef flat.

\section{Goreau Diving Buoy series}

Samples from $25 \mathrm{~cm}$ below MSL at T. F. Goreau Diving Buoy, at toe of $A$. cervicornis reef escarpment. Dated to study framework reef growth of actively advancing fore-reef escarpment, and submarine lithification.

\section{Tx-928. JS-Mine 1,3 coral}

$$
\begin{array}{r}
1520 \pm 100 \\
\text { A.D. } 430 \\
\delta C^{14}=-171 \pm 6.8 \% o
\end{array}
$$

Coral (aragonite, Montrastrea cavernosa) from E side of excavation, $90 \mathrm{~cm}$ beneath reef front, immediately below Tx-929.

\section{Tx-929. JS-Mine 1,3 crust}

$$
\begin{aligned}
\mathbf{1 0 7 0} \pm 70 \\
\text { A.D. } 880 \\
\delta C^{14}=-\mathbf{1 2 5} \pm \mathbf{5 . 8} \%
\end{aligned}
$$

Submarine crust rich in Mg-calcite, immediately overlying Tx-928.

\section{Tx-930. JS-Mine 1,2}

$1400 \pm 70$

$$
\delta \boldsymbol{C}^{14}=-\mathbf{\text { A.D. 550 }}=\mathbf{1 6 0} \pm \mathbf{5 . 7} \%
$$

Coral (aragonite, Montrastrea annularis), $120 \mathrm{~cm}$ beneath reef front, $25 \mathrm{~m}$ below MSL, at base of excavation as it existed at end of summer 1969.

General Comment (L.S.L.): lithification of internal sediment is a rapid process, and only ca. $400 \mathrm{yr}$ separates growth of coral, its burial in sediment, and lithification of the sediment. Rate of vertical growth of reef at $-25 \mathrm{~m}$ is ca. $1.2 \mathrm{~m} / 1000 \mathrm{yr}$, and not much slower at $-35 \mathrm{~m}$.

\section{ARCHAEOLOGIC SAMPLES}

\section{A. Arkansas}

Samples subm. by M. P. Hoffman, Dept. Anthropol., Univ. Arkansas, Fayetteville. For discussion of chronology of sites, see Hoffman (1970). Comments by E. M. Davis. 
Tx-577. Powell Mound

Charcoal from center post hole in pre-mound structure, Powell Mound (3CL9), $0.4 \mathrm{~km}$ due S of Stoes Ford across Caddo R., in De Gray Reservoir Basin, Clark Co., Arkansas (34 $16^{\prime} \mathrm{N}$ Lat, 93 $18^{\prime} \mathrm{W}$ Long). Coles Creek component, stratigraphically below Haley focus component. Previous date from this component is Tx-110, $820 \pm 80$ (R., 1965, v. 7, p. 307). Coll. 1964 by D. F. Green. Comment: date agrees with Tx-110 but seems late for a Coles Creek component.

\section{Tx-579. Battle Place}

$210 \pm 50$

Charred corn cobs from probable storage or refuse pit assoc. either with lower floor of Structure 1 or with mound fill, Battle Mound (3LAl), on E side flood plain of Red R., $8 \mathrm{~km} \mathrm{~W}$ and $8 \mathrm{~km} \mathrm{~S}$ of Lewisville, Lafayette Co., SW Arkansas ( $33^{\circ} 18^{\prime} \mathrm{N}$ Lat, $93^{\circ} 41^{\prime} \mathrm{W}$ Long). Structure 1 represents Haley focus component. Date is average of 2 separate preparations and counts: $130 \pm 70$ and $290 \pm 60$. Coll. 1948 by L. Howard. Comment: if $200 \mathrm{yr}$ is added to age to correct for fractionation in photosynthesis in corn (Bender, 1968, corroborated by experience in our lab), date is still ca. $200 \mathrm{yr}$ more recent than expected for Haley focus.

\section{White Cliffs series}

Charcoal samples from White Cliffs site (3LR2), near bank of Little R. ca. $24 \mathrm{~km} \mathrm{NE}$ of Ashdown, Little River Co., SW Arkansas, in Millwood Reservoir basin (33 $46^{\prime} \mathrm{N}$ Lat, $94^{\circ} 03^{\prime} \mathrm{W}$ Long). Millers Crossing phase, early Caddoan.

\section{Tx-578. White Cliffs 166}

Beam in burned structure on old ground surface under Mound 2. Coll. 1965 by J. Rawlinson.

\section{Tx-581. White Cliffs 1039}

$$
650 \pm 70
$$
Scholtz.

Roof fall in burned structure under Mound 1. Coll. 1961 by J. A.

General Comment: dates consistent, but 2 centuries more recent than expected for Millers Crossing phase.

\section{Bell site series}

Charcoal samples from Bell site (3HO11), $11.3 \mathrm{~km} \mathrm{~N}$ of Millwood Dam, $1 \mathrm{~km} \mathrm{E}$ of Mine Creek, tributary of Saline R., in Millwood

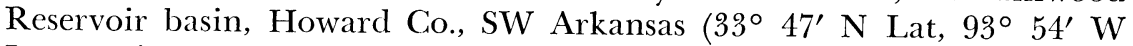
Long). Site has 2 components: Hutt phase, pre-Caddoan ceramic; Mineral Springs phase, late early Caddo. Coll. 1961 by J. A. Scholtz.

From Pit 44, pre-mound midden. Hutt phase. Comment: date some 
3 centuries more recent than indicated by stylistic and stratigraphic relationships of Hutt phase.

\section{Tx-583. Bell 320}

$630 \pm 70$

From Pit 35, assoc. with upper of 2 round wattle-and-daub houses; same structure as Tx-112, $660 \pm 100$ (R., 1965, v. 7, p. 308). Mineral Springs phase. Comment: agrees well with Tx-112 and with chronologic position of Mineral Springs phase as indicated by archaeologic evidence.

\section{Graves Chapel series}

Charcoal from Mound A of Graves Chapel site (3SV15), E side Saline R. Valley, ca. $11 \mathrm{~km} \mathrm{E}$ of Lockesburg, Sevier Co., SW Arkansas, in Millwood Reservoir basin (34 $50^{\prime} \mathrm{N}$ Lat, $94^{\circ} 01^{\prime} \mathrm{W}$ Long). Upper component is Graves Chapel phase, early Caddoan; lower component is Hutt phase, pre-Caddoan ceramic. Coll. 1964 by M. P. Hoffman.

Tx-580. Graves Chapel, upper house

Roof beam assoc. with upper house floor, Graves Chapel phase. Comment: date consistent with archaeologic evidence of chronologic position of Graves Chapel phase.

\section{Tx-584. Graves Chapel, pre-mound}

$960 \pm 80$

Charcoal from pre-mound midden, Hutt phase. Comment: date seems recent for pre-Caddoan.

\section{Tx-585. Arthur Gaiter, 34-66}

A.D. 1500

$450 \pm 70$

Charred post from Stratum D, Arthur Gaiter Mound, Clark Co., Arkansas $\left(34^{\circ} 05^{\prime} \mathrm{N}\right.$ Lat, $93^{\circ} 10^{\prime} \mathrm{W}$ Long). Mid-Ouachita focus, protohistoric Caddoan. Coll. 1934 by S. C. Dellinger. Comment: date consistent with position in Caddo style sequence.

\section{Tx-694. Shane's Mound, first part}

$3350 \pm 80$ 1400 B.C.

Tx-694A. Shane's Mound, second part

$$
1730 \pm 120
$$

A.D. 220

Charred bone from central cremation in Shane's Mound (3LA4), E side Red R. near Field Bayou, Lafayette Co., SW Arkansas $\left(33^{\circ} 26^{\prime} \mathrm{N}\right.$ Lat, $93^{\circ} 40^{\prime} \mathrm{W}$ Long). Early Ceramic, Bellevue phase, Marksville-like. Coll. 1959 by H. Kitchens. Comment: dates are on different parts of same sample, prepared and counted independently. Tx-694 was so far from expected age that second part was dated. Tx-694A is within expected age of Marksville-like material.

\section{Tx-695. Old Martin 198}

$2100 \pm 110$ 150 B.C.

Burned bone fragments from midden in Old Martin site (3LR49), $5.6 \mathrm{~km} \mathrm{~N}$ of Millwood Dam in Millwood Reservoir basin, Little River 


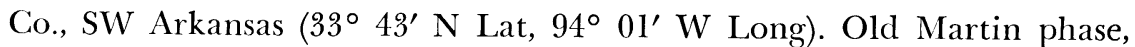
Coles Creek culture. Coll. 1963 by R. Thomas. Comment: date far too old for Coles Creek.

\section{B. Oklahoma}

Samples subm. by R. E. Bell, Dept. Anthropol., Univ. Oklahoma, Norman, Okla.; comments by D. G. Wyckoff, Oklahoma Archaeol. Survey, Norman.

\section{Tx-819. Horton, Feature 4}

$1120 \pm 100$

Charcoal from Feature 4, Trench M, Horton site (Sq-11; Wyckoff, 1970), $6 \mathrm{~km} \mathrm{~S}$ of Vian, Oklahoma, N of Arkansas R (35 $27^{\prime} 15^{\prime \prime} \mathrm{N}$ Lat, $94^{\circ} 58^{\prime} 30^{\prime \prime} \mathrm{W}$ Long). From burned midden with materials comparable to Gibson-aspect Caddoan. This is early component at site; later component has been dated (R., 1970, v. 12, p. 262) at $440 \pm 90(\mathrm{Tx}-627)$ and $780 \pm 70$ (Tx-618; date believed anomalously early). Coll. 1967 by Wyckoff. Comment: although sample is from early context at site, it is earlier than assoc. cultural materials indicate and may represent wood older than context.

\section{Edwards II series}

Charred log fragments from pits in Edwards II site (Bk-44), W bank of North Fork of Red R., $8 \mathrm{~km} \mathrm{~S}$ of Sayre, Beckham Co., Oklahoma (35 $14^{\prime} \mathrm{N}$ Lat, $99^{\circ} 33^{\prime} \mathrm{W}$ Long). Site has one component with small triangular notched and un-notched points, small stemmed points, worked bone, cord-marked pottery; resembles Custer focus material. Coll. 1968 by A. D. Buck.

\section{Tx-807. Edwards II, Feature 8}

Tx-808. Edwards II, Feature 7

\section{Tx-809. Edwards II, Feature 3}

$1140 \pm 70$ A.D. 810

$980 \pm 70$ A.D. 970

$1100 \pm 80$

A.D. 850

General Comment: dates are consistent, and agree with M-1091, $1000 \pm$ 100 (R., 1965, v. 7, p. 132), from Mouse site, a Custer-focus site.

\section{Edwards I series}

Charcoal samples from Edwards I site (Bk-2), W bank of North Fork of Red R., $8 \mathrm{~km} \mathrm{~S}$ of Sayre, Beckham Co., Oklahoma $\left(35^{\circ} 14^{\prime} \mathrm{N}\right.$ Lat, $99^{\circ} 33^{\prime} \mathrm{W}$ Long). Site has small notched and un-notched points, obsidian, Southwestern glazed sherds, Dismal River-like pottery; seems very late prehistoric. Coll. 1968 by A. D. Buck.

Tx-810. Edwards I, \#1

$310 \pm 70$

From Post Hole \#3. 
Tx-811. Edwards I, \#2

$$
200 \pm 70
$$

From large circular ditch, probably a fortification; $281 / 2$ in. (72.4 $\mathrm{cm})$ below surface in Sq. S11-L15.

\section{Tx-812. Edwards I, \#3}

$\mathbf{5 5 0} \pm \mathbf{7 0}$

From Post Hole in Sq. S12-R5.

A.D. 1400

Tx-813. Edwards I, \#4

A.D. 1660

From Post Hole \# 1 .

\section{Tx-814. Edwards I, \#5}

A.D. 1500

$$
450 \pm 70
$$

From Post Hole \#2.

General Comment: site may have more than one component, but dates agree with artifact styles in indicating very late prehistoric or protohistoric occupation.

\section{Clement site series}

Samples from Glement site (Mc-8), W bank of Glover Creek, $1.6 \mathrm{~km}$ $\mathrm{N}$ of Glover, McCurtain Co., SE Oklahoma $\left(34^{\circ} 10^{\prime} \mathrm{N}\right.$ Lat, $94^{\circ} 10^{\prime} \mathrm{W}$ Long). This is one of sites from which McCurtain focus is defined; pottery styles appear to be early McCurtain focus. Site had mound with 2 stratigraphic units, and pre-mound occupation. Coll. 1941 by D. A. Baerreis.

Tx-823A. Clement 4, wood

Tx-823B. Clement 4, corn cob

Sq. 22:8, below mound unit. Comment (S.V., Jr.): difference between dates on wood and corn is about as expected.

\section{Tx-824. Clement 5, corn cobs} A.D. 1760

$$
\begin{array}{r}
390 \\
\text { A.D. } 1560
\end{array}
$$

$$
140 \pm 140
$$

Modern

From "post hole" in Sq. 22:8, beneath mound unit.

\section{Tx-825. Clement 6, corn cobs}

A.D. 1600

$$
190 \pm 70
$$

Layer no. 2, ash mix, in Sq. 25:10, beneath mound unit.

Tx-829. Clement 10, corn cobs

$$
140 \pm 70
$$

Feature C-6, cache pit at base of mound unit.

Modern

\section{Tx-821. Clement 2, corn cobs} A.D. 1690

$$
260 \pm 70
$$

Sq. 23:7, in or near post mold at base of mound unit.

Tx-826. Clement 7, corn cobs

$$
160 \pm 70
$$

A.D. 1790 
Tx-827. Clement 8, corn cobs

A.D. 1200

$750 \pm 80$

Sq. 24:5, post hole, pre-mound or time of mound construction.

Tx-820. Clement 1, corn cobs

$250 \pm 70$

Sq. 21:9, Feature A-14, relating to period between construction of lower and upper mound units.

\section{Tx-828. Clement 9, wood}

A.D. 1330

$620 \pm 70$

Post in NE corner Burial 3, shaft burial intrusive in last construction unit of mound. Artifacts in burial suggest early McCurtain focus: Avery Engraved, Nash Neck Banded, East Incised vessels, ear spools, pearl and shell beads, Southern Cult materials.

\section{Tx-822. Clement 3, wood}

$1690 \pm 80$

NW center post of 4-center-post house, House 1, in Sq. 59:37. Artifacts suggest early Fulton aspect.

General Comment: allowing for normalization of dates on corn samples (Hall, 1967), time range for site, A.D. 1300 to 1550, agrees well with other estimates (Wyckoff, 1967). However, sequence of dates from mound unit is not consistent with stratigraphic sequence, and early date of Tx-822 from house is in conflict with evidence of assoc. artifact styles indicating later date than other samples. Tx-828 from shaft burial has particular significance in indicating time of early McCurtain-focus development.

\section{Lawrence site series}

Charcoal samples from Lawrence site (Nw-6; Baldwin, 1969), E bank Verdigris R ESE of Nowata, NE Oklahoma $\left(34^{\circ} 41^{\prime} \mathrm{N}\right.$ Lat, $95^{\circ} 33^{\prime} \mathrm{W}$ Long). Samples are from base of black, indurated midden concentration within inclusions of fired clay. Assoc. artifacts are obsidian, linear flakes, and "blades". Site is thought to be Late Archaic, partly contemporary with Woodland cultures to NE. Coll. 1968 by Bell and Prewitt.

Tx-815. Lawrence, \# I

$2710 \pm 70$

1760 B.c.

Feature 4 fill, Sq. S25EO, 3.3 to $3.5 \mathrm{ft}$. (0.92 to $1.07 \mathrm{~m}$ ) below basic control elev.

\section{Tx-816. Lawrence, \#2}

$3460 \pm 110$

Feature 10 fill, Sq. S15E15, 4.0 to $4.5 \mathrm{ft}$. (1.22 to $1.37 \mathrm{~m})$ below basic control elev.

Tx-817. Lawrence, \#3

$3090 \pm 140$

Feature 2 fill, Sq. S25W10, 3.5 to $4.0 \mathrm{ft}$. (1.07 to $1.22 \mathrm{~m}$ ) below basic control elev. 
Tx-818. Lawrence, \#4

Sq. S30W5, 4.0 to $5.0 \mathrm{ft}$. (1.22 to $1.52 \mathrm{~m})$ below basic control elev., below base of midden.

General Comment: dates, before 1000 B.c., lessen probability of contemporaneity with Woodland cultures. Variability of dates supports archaeologic evidence of several periods of site utilization.

\section{Currie Site series}

Samples from remains of burned house at Currie site (Gv-22), on W bank Washita R., $8 \mathrm{~km} \mathrm{~S}$ of Pauls Valley, Oklahoma (34 $36^{\prime} \mathrm{N}$ Lat, $97^{\circ}$ $11^{\prime} \mathrm{W}$ Long). House is probably late Plains Woodland, but may be early Washita River focus. Coll. 1968 by Bell and Prewitt.

Tx-830. Currie 1: corn cobs

A.D. 1310

Sq. D2 at base of house fill.

Tx-831. Currie 2

$\mathbf{7 8 0} \pm \mathbf{7 0}$

Wood charcoal from Sq. D2 in house debris zone.

\section{Tx-832. Currie 3}

$710 \pm 70$

Burned thatch from Sq. D3, house debris zone.

Tx-833. Currie 4 .

A.D. 1080

A.D. 1240

Wood charcoal, fragment of small post, in Sq. D5, in house debris zone.

Tx-874. Currie 5

$1130 \pm 120$

Burned thatch, NE corner of Sq. B5.

A.D. 820

Tx-856. Currie 6

$90 \pm 70$

Burned thatch, Sq. B5, on floor of house.

Modern

Tx-857. Currie 7

$560 \pm 80$

Burned thatch, Sq. A5.

\section{Tx-858. Currie 8}

Burned thatch and a few vine fragments, Sq. B5.

$$
830 \pm 50
$$

A.D. 1120

Tx-859. Currie 9

$1070 \pm 80$

Charred $\log$, Log M, NE corner of Sq. A4.

$910 \pm 70$

Tx-860. Currie 10

A.D. 1040

Charred $\log$, Log DD, from Sq. AA5. 
Tx-861. Currie 11

Charred log, Log CC, from Sq. AA4.

Tx-862. Currie 12

$800 \pm 70$

A.D. 1150

$$
560 \pm 70
$$

A.D. 1390 ing thatch to house exterior.

\section{Tx-863. Currie 13}

A.D. 1100

$850 \pm 60$

Burned vine, Sq. A5. Vine appears to have covered house wall.

\section{Tx-864. Currie 14}

$$
650 \pm 70
$$
wall.

Burned vine over $\log$ A, Sq. B5. Vine appears to have covered house

\section{Tx-865. Currie 15}

$580 \pm 70$

Burned $\log , \log$ A, Sq. B5.

General Comments: charcoal dates (except Tx-859, -865 which are anomalous), and corn date Tx-830 with 250 yr correction, indicate time span ca. A.D. 1050 to 1150 , supporting hypothesis that site represents very early phase of culture that eventually developed into Washita River focus, ca. A.D. 1150 to 1375 (Bell, 1968). (S.V.,Jr.): reasons for highly varied dates from thatch and vine are not apparent.

\section{Texas}

Charcoal from Palestine Reservoir basin, upper Neches R., Anclerson and Henderson Cos., E Texas. Dated as supplement to seriation and attribute analysis in distinguishing Alto focus (earlier) from Frankston focus (later) components. Coll. 1969-70 by Keith Anderson; subm. by Kathleen Gilmore, Dept. Anthropol., Southern Methodist Univ., Dallas, Texas.

\section{X41AN3 series}

Samples from Site 41AN3, W bank Neches R., $6.5 \mathrm{~km}$ E of Frankston (32 $04^{\prime} \mathrm{N}$ Lat, $95^{\circ} 26^{\prime} \mathrm{W}$ Long). Frankston focus component.

\section{Tx-1275. X41AN3-4-1}

$230 \pm 70$

\section{Tx-1276. X41AN3-2-4}

A.D. 1720

A.D. 1590

$$
360 \pm 70
$$

Two separate dates on fragments of post later than initial site occupation, capped by midden soil of Frankston occupation. Feature 2 trench, $30 \mathrm{~cm}$ from $\mathrm{W}$ wall, $50 \mathrm{~cm}$ from $\mathrm{E}$ wall, 20 to $40 \mathrm{~cm}$ below surface. Comment (K.A.): although dates do not disagree, and indicate late Frankston focus, they are sufficiently divergent to be inconclusive. Possibility that post is recent fence post cannot be excluded, but is unlikely. 


\section{X41HE37 series}

Samples from Site X41HE37, W bank Neches R., $10.8 \mathrm{~km} \mathrm{NE}$ of Frankston $\left(32^{\circ} 09^{\prime} \mathrm{N}\right.$ Lat, $95^{\circ} 29^{\prime} \mathrm{W}$ Long), from lower half of Frankstonfocus cultural deposit.

\section{Tx-1279. X41HE37-1-12}

Feature 1, 20 to $30 \mathrm{~cm}$ below surface.

\section{Tx-1280. X41HE37-11-1}

Feature 4, 30 to $40 \mathrm{~cm}$ below surface. General Comment (K.A.): Tx-1279 within expected time range. No explanation evident for early age of Tx-1280.

\section{Tx-1273. X41HE40-11-1} $120 \pm 140$

From Feature 11, 60 to $70 \mathrm{~cm}$ below surface, small charcoal-filled pit originating at lower levels of occupation, in Site X41HE40, on Caney Creek, W tributary of Neches R., $12.1 \mathrm{~km} \mathrm{~N}$ of Frankston $\left(32^{\circ} 09^{\prime} \mathrm{N}\right.$ Lat, $95^{\circ} 29^{\prime} \mathrm{W}$ Long). Should give date for Alto-Frankston transition. Comment (K.A.): reason for modern age not apparent in field data.

General Comment (K.A.): Tx-1275, -1276, and -1279 are within expected time range; others are not. Series does not help with Alto-Frankston chronology.

\section{Hualfin Valley, Argentina}

Charcoal from sites in Hualfín Valley, Catamarca Prov., NW Argentina, dated to obtain further information on sequence in this valley, which provides a chronologic key for NW Argentina. Coll. 1969 and subm. by Alberto Rex González, La Plata Mus., La Plata, Prov. Buenos Aires, Argentina; comments by A. R. G. In sample titles, nos. preceded by “\#” are catalog nos. in $\mathrm{C}^{14}$ files, Dept. Archeol., La Plata Mus.

\section{Tx-981. Río Diablo 1, \#95}

$2490 \pm 80$

Test 1, Layer 2, at Río Diablo Site 1, $3.5 \mathrm{~km} \mathrm{~N}$ of La Cienaga, Dept. Belén (27 29' S Lat, $66^{\circ} 58^{\prime} \mathrm{W}$ Long). Type site of Río Diablo phase, Condorhuasi culture. Coll. by M. Sempé. Comment: Diablo phase was thought to date A.D. 100-150, but Tx-981 and Trondheim date T-903 (Rex González, pers. commun.) from nearby Site 2 indicate phase is several hundred yr older.

\section{La Manga series}

Tx-982. La Manga 4, \#98 bis

Test Trench 2, Level II, Layer A, La Manga 4 site, $2.9 \mathrm{~km} \mathrm{~N}$ of La

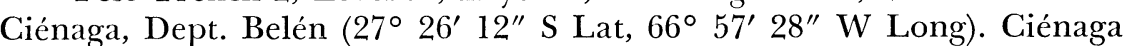
I phase. Coll. by A. Rizzo and C. Sempé. 
Tx-983. La Manga 4, \#96

Test Trench 2, Level II, Layer B, La Manga 4 site. Should be slightly older than Tx-982. Coll. by A. Rizzo and C. Sempé.

General Comment: other dates on Ciénaga I phase are UCLA-785A, $1680 \pm 80$ (R., 1967, v. 9, p. 485) and T-902, $1980 \pm 70$ (Rex González, pers. commun.). Tx-982 agrees with T-902 and Tx-983 is consistent with expectations for Tx-982. Río Diablo phase appears to date in 1st or 2nd century B.c.

\section{Tx-984. Saujil 1, \#51}

$2400 \pm 80$

Stratigraphic Test 5, Layer 3 (0.6 to $0.8 \mathrm{~m})$, Saujil 1 site, $15 \mathrm{~km} \mathrm{~N}$ of Fiambalá, Dept. Tinogasta $\left(28^{\circ} 26^{\prime} 30^{\prime \prime} \mathrm{S}\right.$ Lat, $67^{\circ} 36^{\prime} 30^{\prime \prime} \mathrm{W}$ Long). Type site of Saujil culture. Coll. by D. García and A. R. González. Com ment: previous dates from Saujil culture are O-2147, $1950 \pm 105$, from Saujil 1 and O-2159, $1750 \pm 105$, from lowest layer of Costa de Reyes site (Rex González, pers. commun.). Tx-984 is significantly older than these dates.

\section{Agua Verde series}

Samples from Agua Verde Sites 1 and 5, respectively $2 \mathrm{~km} \mathrm{~W}$ and $3 \mathrm{~km}$ E of Puerta del Corral Quemado, Dept. of Belén $\left(27^{\circ} 27^{\prime} \mathrm{S}\right.$ Lat, $66^{\circ}$ $57^{\prime}$ W Long) Hualfín culture, Agua Verde phase. Coll. by M. D. Arena and C. Sempé.

Tx-985. Agua Verde 1, \#85

Test 1, Layer 1, Agua Verde Site 1.

Tx-986. Agua Verde 5, \#102

Test 1, Level II (0.35 m), Agua Verde Site 5.
$1450 \pm 70$

A.D. 500

$$
1490 \pm 60
$$

A.D. 460

General Comment: other dates for Hualfín (Sanagasta) culture, from Barranca Larga, Agua Verde, and Quillay sites, are: IVIC-184, $1460 \pm$ 90 (R., 1966, v. 8, p. 210), and IVIC-185, $790 \pm 270$ (on bone) (R., 1967, v. 9, p. 241); UCLA-785B, $935 \pm 80$ (ibid., p. 485); T-904, $1400 \pm 70$ (Rex González, pers. commun.). These dates fall into 2 groups; Tx-985 and -986 agree with earlier group, IVIC-184 and T-904, ca. 1450 B.P.

\section{La Aguada culture series}

Tx-992. Cuesta de Zapata, \#58

$$
1750 \pm 50
$$

Test 2, Layer 2 (0.4 to $0.6 \mathrm{~m}) \mathrm{Km} 7611$ site, Cuesta de Zapata, $19 \mathrm{~km}$ $\mathrm{N}$ of Tinogasta, Dept. of Tinogasta $\left(27^{\circ} 57^{\prime} \mathrm{S}\right.$ Lat, $67^{\circ} 24^{\prime} \mathrm{W}$ Long). Aguada Culture Phase II. Coll. by D. García and A. R. González. 
Tx-987. Cuesta de Zapata, \#59

Test 2, Layer 3, Km 7611 site, Cuesta de Zapata (see Tx-992). Coll. by D. García and A. R. González.

Tx-988. Rio Diablo 3, \#89

$1810 \pm 80$

Grid A, Level II, Rio Diablo 3 site, at Rio del Diablo, $3.5 \mathrm{~km} \mathrm{~N}$ of La Ciénaga, Dept. of Belén (27 $26^{\prime} 54^{\prime \prime} \mathrm{S}$ Lat, $66^{\circ} 57^{\prime} 25^{\prime \prime} \mathrm{W}$ Long). Aguada culture. Coll. by A. Rizzo.

General Comment: previous dates for La Aguada culture, from N. de la Ciénaga site, are: L-307, $1130 \pm 90$ (Broecker and Kulp, 1957, p. 1329); U-155, $1180 \pm 85$ (R., 1960, v. 2, p. 124); P-343, $1210 \pm 54$ (R., 1962, v. 4, p. 157). From Cuesta de Zapata site: O-2148, $1700 \pm 105$ (Rex González, pers. commun.); ML-331, $1230 \pm 85$ (ibid). Present series agrees with O-2148 and gives age ca. 1750 в.P. Other dates form a group ca. 1200 в.P. Evidence does not explain disagreement.

\section{Belén culture series}

Tx-989. El Molino, \#102 bis

$$
930 \pm 70
$$

From floor of Rm. 68 in "El Molino" prehistoric village, W of Puerta del Corral Quemado, Dept. of Belén $\left(27^{\circ} 26^{\prime} \mathrm{S}\right.$ Lat, $66^{\circ} 58^{\prime} \mathrm{W}$ Long). Belén culture, late prehistoric. Coll. by C. Sempé.

Tx-990. El Eje, \#82

$1040 \pm 70$

From floor of Rm. 37, "El Eje" village, $4 \mathrm{~km} \mathrm{~W}$ of El Eje de Hualfín, Dept. of Belén (27 $17^{\prime} \mathrm{S}$ Lat, $67^{\circ} 52^{\prime} \mathrm{W}$ Long). Belén culture. Coll. by C. Sempé.

Tx-991. El Eje, \#98

$$
\begin{array}{r}
1090 \pm 60 \\
\text { A.D. } 860
\end{array}
$$

From floor of Rm. 72, "El Eje" village (see Tx-990). Belén culture. Coll. by M. D. Arena.

General Comment: archaeologic evidence places samples either at end of Belén II or beginning of Belén III, about time of arrival of Incas in NW Argentina, ca. A.D. 1480. Present series, while internally consistent, is much earlier. No explanation for discrepancy.

\section{Ai series, Israel}

\section{E. Israel}

Charred wood (except where noted) from Ai (et-Tell), Early Bronze age site ca. $10 \mathrm{~km} \mathrm{NNE}$ of Jerusalem, Israel $\left(31^{\circ} 55^{\prime} \mathrm{N}\right.$ Lat, $35^{\circ} 16^{\prime} \mathrm{E}$ Long). Samples cover whole history of site, from EB I through EB IIIB. EB II artifacts cross-date with late First Dynasty in Egypt; Egyptian alabasters in EB III phases are assoc. with Dynasties II and III. Coll. 1964, 1966 and subm. by Joseph A. Callaway, Southern Baptist Theo- 
logical Seminary, Louisville, Kentucky. In sample titles, letter after title denotes site and figures designate area, sub-area, and layer; thus, A III 204.6 indicates Site A, Area III, Sub-area 204, Layer 6.

\section{Tx-1026. Ai, A III 204.6; EB II}

$4740 \pm 90$ building.

B II destruction debris rearranged for construction of an EB IIIA

\section{Tx-1027. Ai, A IV 300.9a; EB I}

$4920 \pm 90$

Charred reinforcement timber from EB I brick wall, used in EB II mixed with rearranged destruction debris for construction of EB IIIA building.

Tx-1028. Ai, A IV 300.16 EB II

$4800 \pm 90$

Destruction debris of EB II building.

2850 B.C.

\section{Tx-1029. Ai, A IV 300.19; EB II}

$4570 \pm 120$ for construction of EB IIIA fortification tower.

Tx-1030. Ai, C I 1.28b

$4700 \pm 50$

Charred seeds from destruction of EB II building. Sample was split and parts prepared and counted separately: $4630 \pm 70,4770 \pm 90$.

\section{Tx-1031. Ai, C IX 800.10; EB II}

$4730 \pm 90$

2780 B.C.

Charred seeds from destruction layer of EB II building; should be same age as Tx-1030.

\section{Tx-1032. Ai, D IV 300.5; EB I}

$4940 \pm 90$

Destruction debris of EB I building.

Tx-1033. Ai, G VI 500.6; EB IIIB

Destruction debris of EB IIIB building.

2990 B.C.

Tx-1034. Ai, C VII 600.19; EB I

$4400 \pm 80$

2450 B.C. urban (EB I) phase.

\section{Tx-1035. Ai, C I 1.31; EB II}

$5120 \pm 70$

3170 B.C. General Comment (J.A.C.): dates indicate end of Pre-urban phase at Ai and beginning of EB I (Urban I) ca. 3100 B.C. EB II began ca. 2900 B.C.. 
These dates agree with new Cambridge Ancient History dating of Egyptian Old Kingdom, with which Palestinian Early Bronze age is cross-dated through artifacts (Hayes, 1962). Tx-1029 and Tx-1030 are slightly recent in view of other 3 dates for EB II. Time span of EB IIIAB suggested by Tx-1026 and Tx-1033 would allow correlation of Egyptian alabasters in Ai EB III with Dynasty III in Egypt.

\section{Central Negev series, Israel}

Samples coll. 1969 and subm. by A. E. Marks, Dept. Anthropol., Southern Methodist Univ., Dallas, Texas. Comments by A. E. M.

\section{Tx-1119. Negev, E22D15/1}

$>37,000$

Ostrich egg shell from Test Pits 1, 6, 8, (Sqs. 1, 6, EE11, P 18), 20 to $90 \mathrm{~cm}$ below present surface, mostly 47 to $90 \mathrm{~cm}$, scattered through deposit, at site Rosh Ein Mor (E22D15), W edge of Nahal Zin Cliff directly above Ein Avdat pool, $2.7 \mathrm{~km}$ SW of Midrasha Sde Boker $\left(30^{\circ} 49^{\prime}\right.$ $34^{\prime \prime} \mathrm{N}$ Lat, $34^{\circ} 45^{\prime} 50^{\prime \prime} \mathrm{E}$ Long). Assoc. with Levantine Mousterian, probably late Mousterian of Levallois facies. Comment: date suggests usefulness of ostrich egg shell in providing at least minimum age for Mousterian.

\section{Tx-1121. Negev, E22D5/8A, 8B}

$15,820 \pm 1730$ 13,870 в.c.

Charcoal from Firepits $\mathrm{A}$ and $\mathbf{B}$, bottom of occupation layer, Site E22D5, W edge of Nahal Zin stream bed, $1.1 \mathrm{~km} \mathrm{SW}$ of Midrashe Sde Boker ( $30^{\circ} 50^{\prime} 24^{\prime \prime} \mathrm{N}$ Lat, $34^{\circ} 46^{\prime} 31^{\prime \prime}$ W Long). Assoc. with Geometric Kebaran A, late Epipaleolithic phase of Kebaran. Large error quoted is due to small sample size. Comment: no previous date on Kebaran A; date is earlier than expected, but might be correct.

\section{Tx-1122. Negev, E22G9/3}

$5960 \pm 100$

Charcoal from Feature 3, a hearth, Site E22G9, S end of Har Harif Plateau, ca. $30 \mathrm{~km} \mathrm{~W}$ of Mitzpe Ramon $\left(30^{\circ} 30^{\prime} 07^{\prime \prime} \mathrm{N} \mathrm{Lat,} 34^{\circ} 33^{\prime} 00^{\prime \prime}\right.$ E Long). Site has 4 deflating firepits, with lithic material of Kebaran-like Epipaleolithic assemblage thinly scattered in area. Comment: date too recent for Epipaleolithic, indicating artifacts and hearths are not assoc.; hearths apparently are Chalcolithic.

\section{Tx-1123. Negev, E22D1/3A/1}

$8170 \pm 180$

Charcoal from large firepit in Feature 3, ca. $32 \mathrm{~cm}$ below surface, Nahal Divshon site (E22D1), floor of Nahal Zin, $3 / 4 \mathrm{~km} \mathrm{SE} \mathrm{of} \mathrm{Midrasha}$ Sde Boker on S side of dry Nahal stream bed $\left(30^{\circ} 50^{\prime} 30^{\prime \prime} \mathrm{N}\right.$ Lat, $34^{\circ} 47^{\prime}$ $10^{\prime \prime}$ E Long). Assoc. with PPN "B" points and other artifacts but lacks sickle blades and grinding stones; also assoc. are Dama mesopotamica and Capra cf. ibex. Previous dates from this complex are mostly from 6250 to 6750 B.c. (Perrot, 1968, p. 391). Comment: date agrees with previous one. 


\section{F. Sudan}

\section{Tx-1124. N34/37, Dongola Ranch}

Ostrich egg shell from surface on Girra formation, Goshahi, Dongola Ranch, Sudan (18 $0^{\prime} 40^{\prime \prime} \mathrm{N}$ Lat, 31 ${ }^{\circ} 2^{\prime} 30^{\prime \prime} \mathrm{E}$ Long). Assoc. with Karat group, pottery complex cross-dated with Early A group of Egypt and late Khartoum Neolithic of Sudan. Coll. 1966 and subm. by A. E. Marks. Comment (A.E.M.): date too recent to agree with cross-dated assemblages; possibly recent ostrich eggs are involved, since sample was from surface.

\section{REFERENCES}

Baldwin, J., 1969, 'The Lawrence site, Nw-6, a non-ceramic site in Nowata County, Oklahoma: Oklahoma Anthropol. Soc. Bull., v. 18, p. 67-118.

Bell, R. E., 1968, Dating the prehistory of Oklahoma: Great Plains Jour., v. 7, no. 2, p. $42-52$.

Bender, Margaret, 1968, Mass spectrometric studies of carbon 13 variations in corn and other grasses: Radiocarbon, v. 10, p. 468-472.

Broecker, W. S. and Kulp, J. L., 1957, Lamont natural radiocarbon measurements IV: Science, v. 126, p. 1324-1334.

Hall, R. L., 1967, Those late corn dates: isotopic fractionation as a source of error in carbon-14 dates: Michigan Archaeologist, v. 13, p. 171-180.

Hayes, W. C., 1962, Egypt - to end of Twentieth Dynasty: Cambridge Ancient History (rev. ed.), v. 1, ch. 6, fasc. 4, p. 1-23

Hoffman, M. P., 1970, Arkansas, in: Davis, H. A. (ed.), Archeological and historical resources of the Red River Basin, Arkansas Archeol. Survey Pubs. Archeol., Research Ser. no. 1.

Land, L. S., Mackenzie, T. F., and Gould, S. J., 1967, Pleistocene history of Bermuda: Geol. Soc. America Bull., v. 78, p. 993-1006.

Perrot, Jean, 1968, La préhistoire palestinienne, in: Dictionnaire de la Bible, suppl., fasc. 43, col. 286-446; Letouzey et Ané, Paris.

Prinz, Martin, 1970, Idaho rift system, Snake River plain, Idaho: Geol. Soc. America Bull., v. 81, p. 941-948.

Wyckoff, D. G., 1967, The archaeological sequence in the Broken Bow Reservior area, McCurtain County, Oklahoma: Stovall Mus. Nat. Hist. and Oklahoma Archaeol. Survey, Norman.

1970, The Horton site revisited: Oklahoma Archaeol. Survey, Studies in Oklahoma's past, no. 1, Norman. 